\title{
Role of Green Peach Aphid Flights in the Epidemiology of Potato Leaf Roll Disease in the Columbia Basin
}

Peter E. Thomas, Research Plant Pathologist, Vegetable and Forage Crop Production, Agricultural Research Service, U.S. Department of Agriculture; Keith S. Pike, Entomologist, Washington State University, Irrigated Agriculture Research and Extension Center, 24106 N. Bunn Road, Prosser, WA 99350-9687; and Gary L. Reed, Superintendent, Hermiston Agricultural Research and Extension Center, Hermiston, OR 97838

\begin{abstract}
Thomas, P. E., Pike, K. S., and Reed, G. L. 1997. Role of green peach aphid flights in the epidemiology of potato leaf roll disease in the Columbia Basin. Plant Dis. 81:1311-1316.

Three distinct and highly predictable green peach aphid (GPA) (Myzus persicae) flights that occur seasonally in the spring, summer, and fall were detected at a southern, central, and northern location in the Columbia Basin of the Northwestern United States. Intensity and timing of the flights was approximately the same at the three locations. Timing and number of alatae captured in the spring and summer flights was associated with heat unit accumulation. The spring flight, which originates on the overwintering peach tree host, colonized but did not introduce potato leafroll virus (PLRV) into virus-free potato plots. The summer flight, which originates from volunteer potatoes and spring herbs originally colonized by the spring flight, did introduce PLRV into virus-free potatoes. The fall flight was too late to affect potato production. When plots contained a point source of PLRV, the virus spread rapidly in a plant-to-plant mode to all plants in plots after aphids arrived in the spring. Rate of spread from point sources of infection was not affected by timing or intensity of the spring flight, but timing of virus spread in the plots depended on time of arrival of the aphids. Once PLRV was introduced to virus-free plots by the summer flight, virus spread to other plants within the plots. GPA overwintered on peach trees. Although GPA apterae and alatae were present on winter annual weed and crop hosts in the fall, none survived winters on these species. In addition to the GPA, one other vector of PLRV, Macrosiphum euphorbiae, was rarely collected in aphid traps. These results suggest that chemical control of aphids could be delayed until mid-July if PLRV-free potato seed were available.
\end{abstract}

Additional keywords: beet western yellows virus, Capsella bursa-pastoris, rapeseed, Sisymbrium altissimum, suction trap

Potato leafroll virus (PLRV) is transmitted by about 10 species of aphids in a persistent manner (6). Aphids acquire the ability to transmit PLRV only by feeding on infected plants. Aphids retain the ability to transmit for life, but the virus is not passed transovarily to offspring produced either viviparously or oviparously. Green peach aphid (GPA) (Myzus persicae [Sulzer]) is the major vector of PLRV worldwide and has been established as the major vector in the Columbia Basin of the

Corresponding author: Peter E. Thomas

E-mail: pthomas@ beta.tricity.wsu.edu

Names are necessary to report factually on available data; however, the USDA neither guarantees nor warrants the standard of the product, and the use of the name by USDA implies no approval of the product to the exclusion of others that may also be suitable.

Accepted for publication 5 August 1997.

Publication no. D-1997-0904-01R

This article is in the public domain and not copyrightable. It may be freely reprinted with customary crediting of the source. The American Phytopathological Society, 1997.
Northwestern United States (12). Beet western yellows virus (BWYV) is related to PLRV, and its interactions with the GPA are similar, if not identical, to those of PLRV (18). Neither virus is transmitted through true seed (18).

The basic biology of the GPA in the Columbia Basin is known $(9,12)$. It normally overwinters there in the egg stage on peach trees (Prunus persica L.), but it may occasionally overwinter in the apterous stage in restricted microclimates at the edge of warm water springs (17). The small spring flight from peach trees distributes the aphids to herbaceous, winter annual and early spring hosts throughout the region. A summer flight begins when spring hosts begin to mature and senesce. This flight distributes aphids to summer hosts. A fall flight from summer hosts begins in September. It distributes aphids and virus to fall-planted crops $(12,14)$ and returns aphids to the overwintering peach host (17). Although aphids returning to peach in the fall may carry PLRV, those that emerge from eggs on peach in the spring are free of PLRV. Because peach cultivars are immune to PLRV, the young aphids cannot reacquire PLRV from the peach (6).
In a previous study (15), we learned that the fall flight of GPA introduces beet western yellows virus (BWYV) to winter rapeseed. However, the spring flight did not introduce BWYV to spring rapeseed (P. E. Thomas, unpublished data). This observation led to the hypothesis that the spring aphid flight may not introduce the related leuteovirus, PLRV, to potatoes.

The question of whether GPA acquire PLRV en route from peach to potato fields during the spring flight is a central issue in developing strategies to control PLRV. If they do not, spring dissemination of PLRV in potato fields would depend entirely on seed sources of the virus within the potato field. Volunteer potatoes (13) and two winter annual weed species that commonly occur in the Columbia Basin-Jim Hill mustard (Sisymbrium altissimum L.) and shepherd's purse (Capsella bursa-pastoris L.) - are infected by PLRV $(2,3)$ and could serve as overwintering hosts of PLRV $(2,13)$. Clearly, aphids of the spring flight could acquire PLRV from these sources en route from peach to potato fields in the spring, but this has not been demonstrated.

One purpose of this study was to determine whether the spring GPA flight acquires PLRV en route from peach to potatoes. We also wanted to determine the timing of GPA flights that occur in the Columbia Basin in relation to heat unit accumulation and determine the role of the summer GPA flight in the epidemiology of PLRV. Finally, we wanted to determine whether other known vectors of PLRV occur in the Columbia Basin.

\section{MATERIALS AND METHODS}

Timing and intensity of aphid migration flights. Flights of aphid species that occur in the Columbia Basin were monitored over a 7-year period at three locations representing the southern (Paterson), central (Prosser), and northern (Ephrata) Columbia Basin using suction traps (1) that capture flying aphids. Suction trapping was supplemented with yellow pan trapping (8) at Prosser over a 4-year period to detect the spring flight at the site of experimental plots used to determine time of infection with PLRV. One pan $(29 \mathrm{~cm}$ in diameter) was placed on the soil surface in an open area on each side of the plots (described below) and in an open area between plots. The yellow pans were washed and filled 
with fresh water each Monday morning, and aphids were collected each day for the next 4 days, counted, and identified.

Experimental plots were examined visually (12 mature leaves per plot were examined) on a weekly basis to determine presence of GPA. During the first week of June, the numbers and species of aphids present on six lower leaves from each plot were determined using Berleze-Turgren funnels (10) to collect the aphids.

Overwintering of GPA was monitored on winter annual weed hosts of PLRV, Jim Hill mustard and shepherd's purse, on winter rapeseed (Brassica napus L. and B. campestris L.), and on peach trees within a 7-mile radius of the experimental plots. Fifty plants of each weed and crop host were examined visually for GPA late in September and October. The same plants were harvested in March, examined visually for aphid eggs, and subjected to the Berleze-Turgren funnel aphid collection method. Peach trees

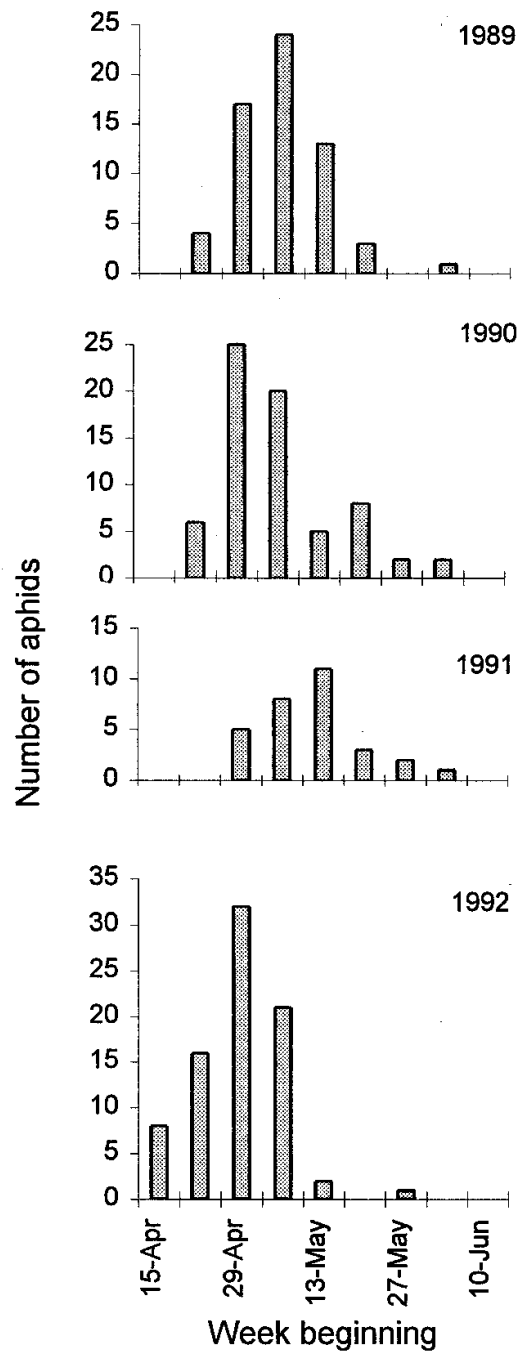

Fig. 1. Time, pattern, and intensity of spring flights of Myzus persicae near Prosser, WA. Number of aphids captured in five yellow pan traps over a 4-day period in each week in 4 years. were examined for aphid colonies in early May.

Heat unit (degree days) accumulation from 1 January data was obtained from the Washington State University Public Agriculture Weather System (7). Heat data for all 7 years of the study were available only for the Prosser location. Data were available from 1989 at Ephrata and from 1991 at Paterson. The following formula was used to calculate heat units accumulated each day: temp $\max \left({ }^{\circ} \mathrm{C}\right)$ - temp $\min$ $\left({ }^{\circ} \mathrm{C}\right) / 2-4.44(7)$.

Statistical analyses were performed using SAS Version 6.1.

Relationship between virus infection and aphid flights. Experimental plots used to detect the introduction and spread of PLRV in potatoes were located near Prosser, WA. The nearest potatoes, which contained PLRV-infected plants, or peach trees where GPA had overwintered was about $800 \mathrm{~m}$.

The incidence and time of PLRV infection was compared in eight virus-free plots and in eight similar plots containing a centrally located PLRV-infected plant. The comparison was repeated in each of 3 years. Plots were $11 \times 12 \mathrm{~m}$. Each contained 13 rows spaced $85 \mathrm{~cm}$ apart, and each row contained 21 , virus-free, in vitroproduced plantlets spaced $60 \mathrm{~cm}$ apart. The eight plots in each group of plots were arranged in a $4 \times 2$ arrangement. Each plot was bordered by $3 \mathrm{~m}$ of open land and then $6 \mathrm{~m}$ of Sudan grass. An additional $20 \mathrm{~m}$ of

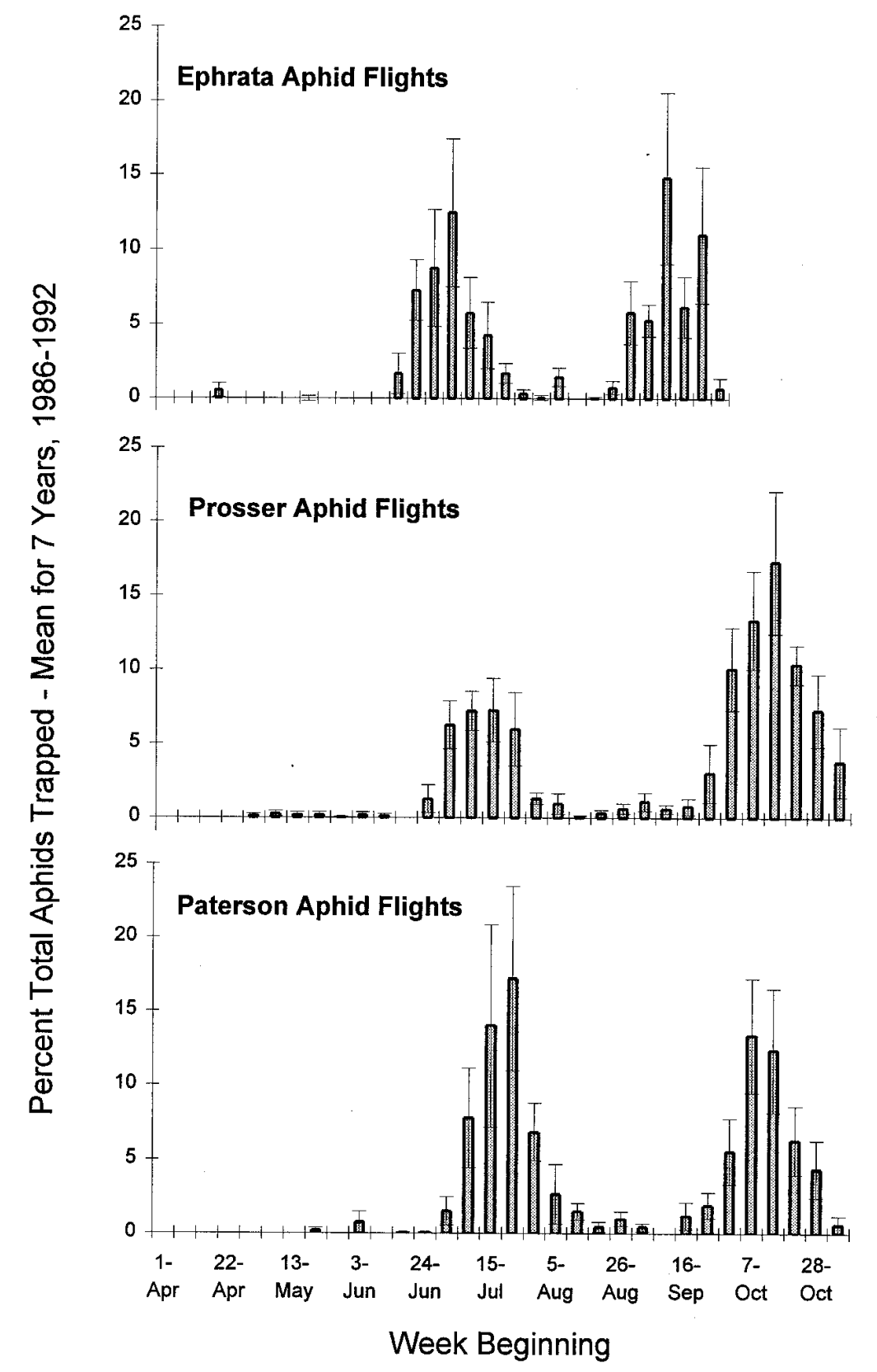

Fig. 2. Time and pattern of Myzus persicae flights at three locations in the Columbia Basin as measured by suction traps. Mean percent of total aphids captured in suction traps each week from 1 April through 3 November during 7 years (1986-1992). Error bars represent standard error. 
open land separated groups of plots containing a central source of inoculum from those without a source of inoculum. Those containing inoculum were located downwind (east) of those without inoculum. The point source of virus was provided by a Russet Burbank plant grown from a PLRVinfected seed piece. In each year of testing, the seed pieces that provided the central virus sources were all derived from the same hill of tubers. The rate and pattern of virus spread in the plots was monitored visually by symptom production. The visual accuracy of these reading were verified by ELISA (5).

\section{RESULTS}

Vector species detected. In addition to the GPA, one other known vector of PLRV, Macrosiphum euphorbiae (Thomas), was rarely captured in suction traps. In seven years, a total of 17 alatae were trapped at Ephrata, 12 at Prosser, and 31 at Paterson. No M. euphorbiae apterae were found in the plots in early June at Prosser when the plots were monitored to determine aphid colonization.

Timing and intensity of GPA migration flights. Migratory flight activity of GPA peaked in the spring (Fig. 1), summer, and fall (Figs. 2). Flying aphids rarely were collected in the interval between the spring and summer flight peaks but commonly were taken in the interval between the summer and fall flights (Fig. 2).

The spring flight, detected by yellow pan traps for 4 years (1989-1992) at the site of the disease assessment plots at Prosser, extended over a period of about 6 weeks in late April and May (Fig. 1). Timing and intensity of the flight varied from year to year. Most aphids (79 aphids) were captured in the earliest flight, in 1992, which began in the week beginning 15 April (Fig. 1, Table 1). The 1989 and 1990 flights began 1 week later and produced 61 and 64 aphids, respectively, while the 1991 flight began 2 weeks later and produced only 30 aphids. By correlation analysis (SAS version 6.10) there was a strong (correlation coefficient $=0.98$ ) and significant $(P<0.05)$ correlation between accumulated heat units (degree days) on 15 May and total number of aphids captured each year. Accumulated heat units on the first day of the week in which the first spring flight aphids were captured was approximately the same each year regardless of starting date (Table 1). Based on the data, timing of the spring flight may be predicted to occur at a degree day range of 304-356 at $P<0.05$.

Suction traps, used to monitor aphid flights at a southern, central, and northern location in the Columbia Basin over a 7-year period, captured some but relatively few spring flight aphids (Fig. 2) compared with yellow pan traps (Fig. 1). However, suction traps readily detected the more massive midsummer and fall flights (Fig 2).
In contrast to the spring flight, the summer GPA flight was characterized by uniformity in starting date (Table 2) but much year-to-year variability in intensity (Fig. 2) at all locations. The first summer flight aphids were taken in the first or second week of July in 18 of the total of 21 measurements (7 years at three locations) (Table 2). At Prosser, the flight began and ended about 1 week earlier and intensity was more uniform throughout the flight than at Paterson or Ephrata (Fig. 2). Flight intensity peaked during the fourth week of July at Ephrata and Paterson. Neither the earlier beginning flight date at Prosser or variability in intensity of the flight could be reliably $(P<0.05)$ predicted solely on the basis of heat unit accumulation using Stepwise logistic regression analysis. However, the odds (odds ratio $=0.995$ ) that the flight would begin increased by a factor of 2.7 at each time increment after June 24. Because heat unit data is available for only 1 year of the study at the Paterson location and only 4 years at the Ephrata location, location effects of heat unit accumulation could not be determined.

The fall GPA flight began late in September and early October (Fig. 2). It was more variable in starting date than the summer flight. Like the summer flight, it began somewhat earlier at Prosser where it was also more intense than at the other locations.

An anomalous GPA flight pattern occurred at Paterson in 1990 when a distinct peak in flight activity occurred in September.

No aphids were observed in any of the experimental plots in any year until after the spring aphid flight began. All of the plots contained GPA apterae in early June in each of the 3 years when plots were grown, but other aphid species were not found in these plots. There were no signifi-

Table 1. Effect of accumulated heat on timing and intensity of spring aphid (Myzus persicae Sulzer) flights at Prosser, WA

\begin{tabular}{lccc}
\hline & \multicolumn{3}{c}{ Accumulated degree days $^{\mathbf{a}}$} \\
\cline { 2 - 4 } Flight start date $^{\mathbf{b}}$ & Start date & $\mathbf{1 5}$ May & Aphids $^{\mathbf{c}}$ \\
\hline 4 April 1989 & 330.1 & 576.7 & 61 \\
16 April 1990 & 329.3 & 576.8 & 64 \\
29 April 1991 & 325.2 & 466.7 & 30 \\
15 April 1992 & 337.0 & 628.9 & 79 \\
\hline
\end{tabular}

${ }^{\text {a }}$ Temp $\max \left({ }^{\circ} \mathrm{C}\right)-$ remp $\min / 2-4.44$, accumulated from 1 January.

${ }^{\mathrm{b}}$ First day of week, month, and year in which first alatae were captured in yellow pan traps.

c Total aphids captured in yellow pan traps.

Table 2. Year-to year consistency (number of years flight started ${ }^{\mathrm{a}}$ ) in starting date of the mid-year aphid (Myzus persicae Sulzer) flight over a 7-year period (1986-1992) at three locations in the Columbia Basin in the Northwestern United States

\begin{tabular}{lcccc}
\hline Location & 24 June & 1 July & 8 July & 15 July \\
\hline Southern (Paterson) & 0 & 2 & 4 & 1 \\
Central (Prosser) & 2 & 4 & 1 & 0 \\
Northern (Ephrata) & 0 & 3 & 4 & 0 \\
Over all locations & 2 & 9 & 9 & 1 \\
\hline
\end{tabular}

a Based on first capture of aphids in suction traps (1). inoculum and those that did not.

Many GPA alatae and apterae were observed on all winter annual weed and crops species examined in late fall in each of the three years that counts were made, but no ds or aphid eggs were observed on the Berleze-Turgren funnels. GPA colonies were always observed on untreated peach in the spring.

and aphid flights. The introduction pattern of spread of PLRV within potato plots correlated with development of Rymptoms. Plants judged to be PLRV produced negative ELISA results at each reading date.

in some plots containing a point source of inoculum 4 weeks after the first aphid alatae were trapped in yellow pans that (Figs. 1 and 3), and new symptoms after the first aphids were trapped. Thus, the earliest new PLRV infections began to appear in 1992 when aphids were trapped arliest. They appeared later by 1 week in alatae arrived 1 or 2 weeks lar, tively (Fig. 3). The latest single plot to develop plants with new symptoms over the 3 years of testing (1991) (Fig. 4), had with symptoms 3 weeks before the in that plot ready had symptoms before the summer flight began. either side of the central virus source plant and in the same row. Symptoms spread in both directions along the row cant differences in numbers between plots were collected from these plants using

The first infected plants always appeared

summer and fall flights (Fig 2).

Based on first capture of aphids in suction traps (1). 
containing the virus source plant at first but later spread to adjoining rows, as foliage in adjoining row began to touch. New infections were always associated with the central virus source plant.

Although time of new symptoms development in plots containing a point source of infection was dependent on the time when alatae arrived in the plots, rate of spread of infection in the plots was not affected by timing or number of aphids in the spring flight (Fig. 3). By logistics curve regression analysis (SAS 6.10, Lifereg Procedure) the infection curves for the three years of testing in plots containing a point source of infection are significantly different in time, but they have a common slope or rate. Although the 1992 flight was earliest and produced most alatae, the rate of spread of virus in plots was the same as for the 1991 flight, which was latest and contained the fewest alatae.

In contrast to the plots that contained a central virus source plant, symptoms did not develop in virus-free plots following arrival of the spring flight. At the earliest, new symptoms began to develop in these plots in the third week of July, 4 weeks after the summer flight began (Fig. 3). Three plots developed first symptoms in the third week of July (one plot in each of 3 years), three developed first symptoms in the fourth week of July (two in 1989 and one in 1991), one developed symptoms in the last week of July in 1992, and one plot developed symptoms in the first week of
August 1989 (Fig. 3). Sixteen of 24 plots that were initially virus-free over the 3 years of these studies remained free of symptoms at the end of the season.

Rate of spread of symptoms after the first plant developed symptoms was initially the same in virus-free plots as in plots that contained a point source of infection and developed symptoms earlier in the year. Only two plots that remained symptom free until 29 July developed new symptoms during the year. These numbers were insufficient to provide a valid statistical comparison, but the actual rate of infection in those plots declined as the season progressed (Fig. 3).

More than one center of infection was never observed in any of the virus-free plots. Location of infection centers occurred randomly in virus free the plots.

\section{DISCUSSION}

The results indicate that dissemination of PLRV depends almost exclusively on one aphid species, $M$. persicae, that is dispersed seasonally in three distinct and highly predictable migratory flights in the Columbia Basin. Thus, control strategies, either chemical or biological, may be targeted on this aphid species, on its dispersal flights, and on the sources of virus disseminated by this aphid.

Both the timing and intensity of the spring aphid flight appears to be strongly influenced by spring heat accumulation. The earliest spring flight occurred in the warmest spring and the latest in the coolest. In an earlier report (12), the spring flight of the GPA was about 2 weeks later near Yakima, WA, than at Prosser in these studies. Yakima, located about 50 miles northwest of Prosser at the foot of the Cascades, has a distinctly cooler climate. During the years of this study, accumulated heat units on 15 May were 14, 19, 17, and $11 \%$ lower, respectively, at Yakima than at Prosser.

The summer flight was characterized by uniformity in starting date at any location. Timing of the summer flight of GPA could not be reliably $(P<0.05)$ predicted solely on the basis of heat unit accumulation by the method of measuring heat that we used (7). However, it was affected by date, which may include heat accumulation as a factor. Additional factors that might affect timing of the flight, but were not studied, include precipitation, as it affects maturity of spring hosts, and day length.

A second vector of PLRV, M. euphorbiae, was detected. Because of its low vector efficiency (about $2 \%$ as efficient as M. persicae) (11), the impact of this aphid on PLRV epidemiology is slight even in regions where it occurs in large numbers (19). Because it occurs rarely in the Columbia Basin, its impact there on the epidemiology of PLRV should be negligible.

The results confirm the hypothesis that the spring flight of GPA rarely, if ever, acquires PLRV en route from the overwintering peach tree host to potato fields.

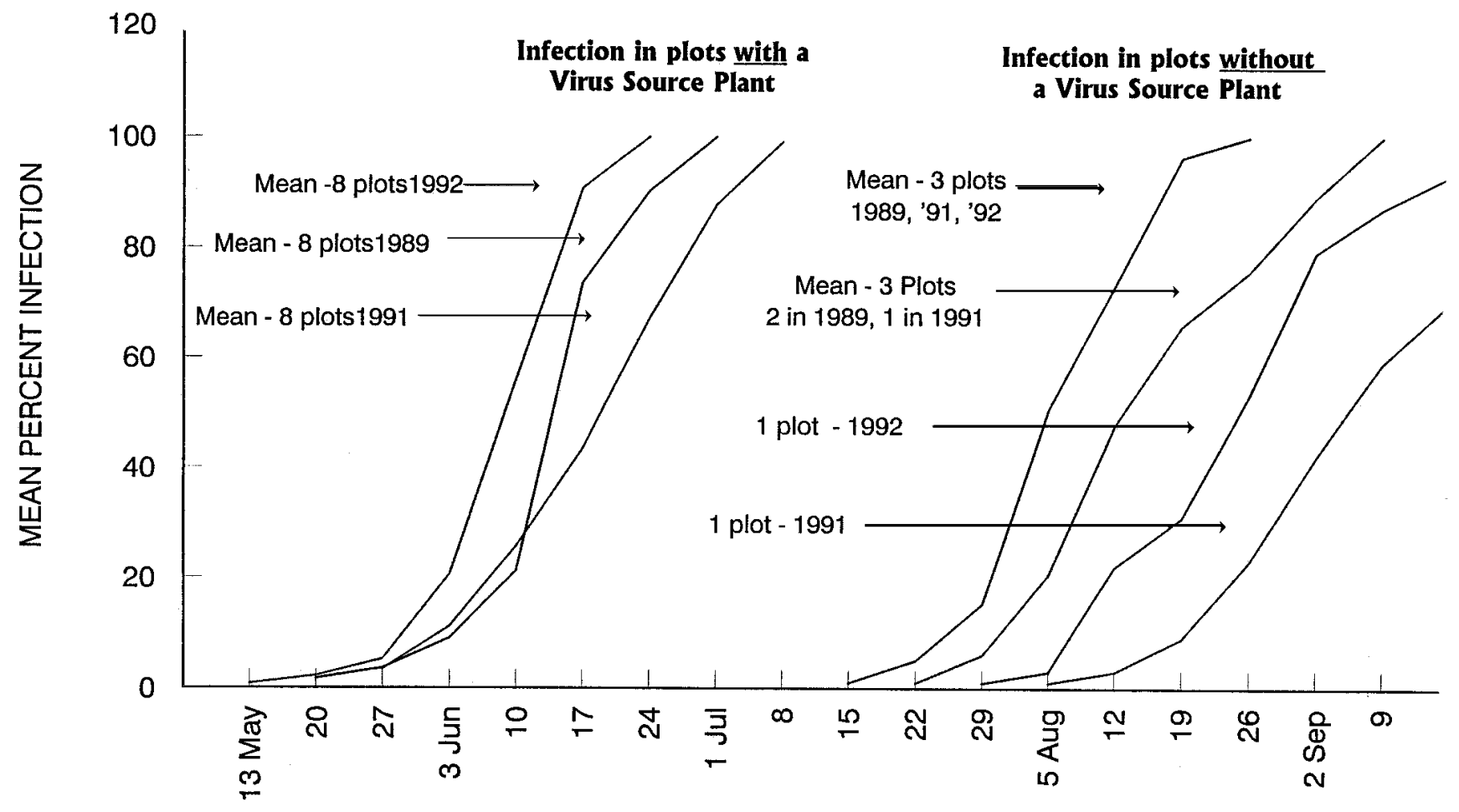

TIME AND RATE OF INFECTION IN PLOTS - WEEK BEGINNING

Fig. 3. Time of appearance of potato leafroll virus symptoms and rate of spread of symptoms in potato plots initially virus free and in plots containing a centrally located infected plant. 
No infection developed in virus-free potato plots after their colonization by aphids of the spring flight. When a virus source was present in plots, virus began to spread rapidly from that source in a plant-to-plant mode soon after the apterous offspring of the spring flight were present.

We do not understand why rate of spread of PLRV in plots containing a point source of inoculum was the same in 1991 as in other years despite the fact that numbers of alatae captured at the site were considerably lower in 1991. Many factors may be involved in rate of plant-to-plant spread from a point source. Numbers of colonizing alatae in the range we trapped may not be limiting.

In contrast to the spring flight, summer flights of GPA introduced PLRV into virusfree potato plots from outside sources. Infection developed in virus-free potato plots after the summer flight began. The time required for symptoms to develop after the summer flight began was about the same as that required for new symptom development in plots containing a point source of infection after the spring flight arrived and approximately equal to the reported incubation period for PLRV in potatoes (16).

Volunteer potatoes and two winter annual weed species $S$. altissimum and $C$. bursa-pastoris are the only known overwintering hosts of PLRV that could provide the virus introduced by the summer flight $(2,3,13)$. Volunteer potatoes were previously (13) implicated as a major source of virus disseminated by the summer flight. While the two weed species can be infected by PLRV, it is not clear that they serve as sources of virus in the epidemiology of PLRV.

The information presented here on the introduction of PLRV to potato fields by aphid flights emphasizes the importance of virus-free potato seed stocks and indicates control strategies for PLRV in the Columbia Basin with reduced use of insecticide. Season-long applications of insecticide are required to control PLRV when inoculum sources exist in the field. In contrast, if seed stocks were virus free, use of insecticide might be delayed at least 60 days. After this time, plants infected by the summer flight of aphids could serve as sources of virus, and insecticides would be required to control PLRV dissemination within the crop. At this late date, only a few insecticide applications would be needed to prevent virus spread until the end of the summer flight. Potatoes become highly resistant to PLRV infection and to damage caused by PLRV as they enter senescence at the end of the season. $(15,19)$.

As an alternative to insecticide, biological control strategies implemented in late June or early July to focus on the midsummer flight might be much more effective in potatoes where an early application of insecticide to control the spring flight was not necessary. Aphid predators would not have been killed by the insecticide used to control aphids, and an abundance of aphid prey in untreated potatoes might stimulate high populations of predators prior to arrival of infective alatae in the summer flight.

The presence of PLRV in potato seed is routinely diagnosed in some seedlots in the Washington State seed lot trials (R. Thornton, personal communication). Because of the risk that any particular seedlot may contain some virus, growers routinely use systemic insecticides to control colonization of potatoes by the spring aphid flight. However, use of insecticide to control colonization of potatoes by the spring flight of aphids is not equivalent to use of virus free seed for virus disease control. Sources of virus in the seed produce chronically infected plants that are preferentially colonized by alatae of the summer flight (G. L. Reed, unpublished data). Thus, aphid control must begin immediately when the summer flight begins if the seed source contains virus, even when the spring flight is controlled. In contrast, with virus free seed, aphid control may be delayed an additional 3 to 4 weeks, until plants initially infected by alatae of the summer flight became sources of virus. An earlier application of insecticide probably would not reduce the number of plants initially infected by alatae of the summer

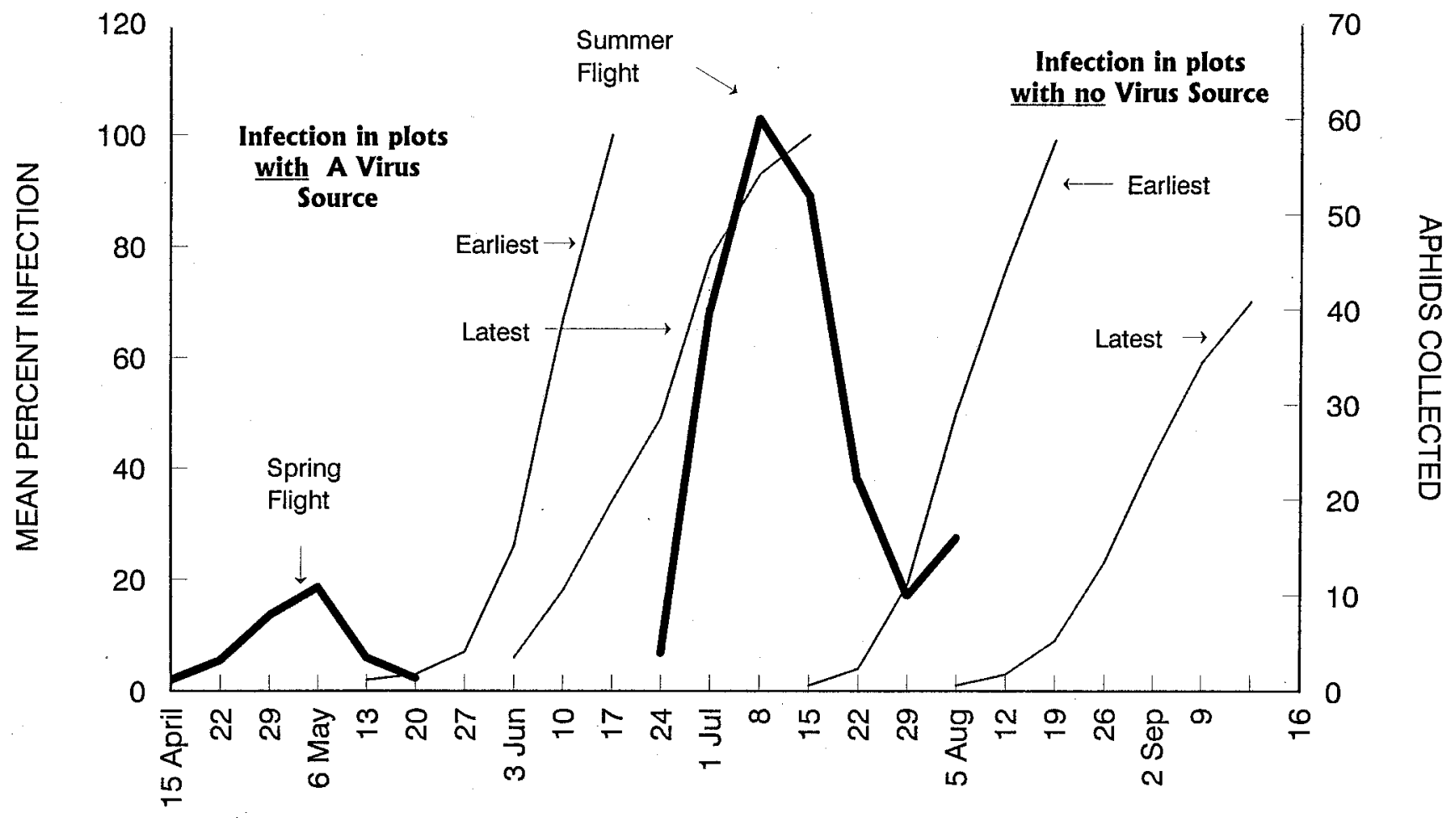

TIME OF INFECTION IN RELATION TO TIME OF APHID FLIGHTS - WEEK BEGINNING

Fig. 4. Relationship between time of aphid (Myzus persicae) flights and time of potato leafroll virus symptom development in virus-free potato plots and in similar plots containing one, centrally located, potato leafroll virus-infected potato plant. Infection curves show the earliest or latest infection recorded over three years among 24 plots (eight plots/year) virus-free and 24 plots containing a source of virus inoculum. The spring flight curve represents mean values for yellow pan trapping and the summer flight curve represents mean values for suction trapping over the same three years at Prosser. 
flight because aphids are able to transmit PLRV before they are killed by systemic pesticides (19).

Although the summer flight certainly introduced PLRV into virus-free plots, the frequency of introduction was low. A similar conclusion may be drawn from the fact (unpublished) that few infection centers, often fewer than one per acre, are involved in epidemics that develop in commercial fields after mid season when growers fail to control aphids.

Our failure to detect overwintering of GPA on herbaceous, winter annual hosts confirms our earlier results (14) and supports the conclusion (12) that overwintering of GPA in the Columbia Basin is restricted to the egg stage on peach under normal conditions. The failure of aphids in the spring flight to initiate infection in virus free potato plots also tends to confirm this, since two of the primary winter annual hosts of the GP aphid in the region (Shepherd's Purse and Jim Hill Mustard) are known to be hosts of PLRV $(2,3)$, whereas peach is not a host of the virus (4).

The basis for the difference in capacity of suction traps as compared with yellow pan traps to reliably measure the spring migration of GPA could reflect a difference in the size of the sector of space sampled by the two methods. Suction traps sample a very limited space at a fixed elevation. Yellow pans may attract aphids over a broad range of elevation. Furthermore, the spring GPA migration, originating only from peach, is much smaller than the summer flight $(9,12)$.

The failure of PLRV to move from one plot to another in these studies is an indi- cation of the degree to which the disease is confined by the mobility characteristics of apterous aphids.

\section{ACKNOWLEDGMENTS}

We thank Guy Reisenauer, scientific programmer, Washington State University, for his assistance with statistical analysis.

\section{LITERATURE CITED}

1. Allison, D., and Pike, K. S. 1988. An inexpensive suction trap and its use in an aphid monitoring network. J. Agric. Entomol. 5:103-107.

2. Fox, L., Biever, D. K., Toba, H. H., Duffus, J. E., and Thomas, P. E. 1993. Overwintering and monitoring of potato leafroll virus in some wild crucifers. Am. Potato J. 70:505515.

3. Hassan, S., Thomas, P. E., and Mink, G. I. 1985. Tomato yellow top virus: host range, symptomatology, transmission, and variability. Phytopathology 75:287-291.

4. Helson, G. A. H., and Norris, D. O. 1943. Transmission of potato virus diseases. 3. Susceptibility of cruciferae to potato leafroll virus. J. Sci. Ind. Res. Austral. 16:261-262.

5. Kaniewski, W. K., and Thomas, P. E. 1988. A two-step ELISA for rapid, reliable detection of potato viruses. Am. Potato J. 65:561-571.

6. Kennedy, J. S., Day, M. F., and Eastop, V. F. 1962. A conspectus of aphids as vectors of plant viruses. Commonwealth Agric. Bureau, Kew, England. 114 pp.

7. Ley, T. W., Willett, M. J., Boyer, J., Wright, M. A., Muzzy, A., and Graves, C. B. 1992. Implementing a real-time weather data acquisition and information delivery system for enhanced crop production in Washington State. Proc. 4th Int. Conf. Computers Agric. Ex. Prog. ASAE Publ. 1-92. ASAE, St. Joseph, MI.

8. Moericke, V. 1951. Eine Farbfalle zur kontrolle des Fluges von Blattlausen, insbesondere der Pfirsiehblattlaus Myzodes persicae (Sulz.). NachrBl. dtsch. PflSchDienst, Stuttgart 3:23-24.
9. Powell, D. M., and Mandor, W. T. 1976. Area control of green peach aphid on peach and the reduction of potato leafroll virus. Am. Potato J. 53:123-139.

10. Southwood, T. R. E. 1966. Ecological methods with particular reference to the study of insect populations. Methuen \& Co., London. $391 \mathrm{pp}$.

11. Tamada, T., and Harrison, B. D. 1981. Quantitative studies on the uptake and retention of potato leafroll virus by aphids in laboratory and field conditions. Ann. Appl. Biol. 98:261276.

12. Tamaki, G., Fox, L., and Butt, B. A. 1979 Ecology of the green peach aphid as a vector of beet western yellows virus of sugarbeets. Tech. Bull. 1599, U. S. Dep. Agric. 16 pp.

13. Thomas, P. E. 1983. Sources and dissemination of potato viruses in the Columbia Basin of the Northwestern United States. Plant Dis. 67:744-747.

14. Thomas, P. E., Evans, D. W., Fox, L., and Biever, K. D. 1990. Resistance to beet western yellows virus among forage brassicas. Plant Dis. 74:327-330.

15. Thomas, P. E., Hang, A. N, Reed, G., Gilliland, G. C., and Reisinhouer, G. 1993. Potential role of winter rapeseed culture on the epidemiology of potato leaf roll disease. Plant Disease 77:420-423.

16. Thomas, P. E., and Zielinska, L. 1983. Use of IKI leafroll test to reduce net necrosis storage losses of potatoes. Am. Potato J. 60:309-320.

17. Wallis, R. L., and Turner, J. E. 1969. Burning weeds in drainage ditches to suppress populations of green peach aphids and the influence of beet western yellows disease in sugarbeets. J. Econ. Entomol. 62:307-317. 1969.

18. Waterhouse, P. M., Gildow, F. E., and Johnstone, G. R. 1988. Leuteovirus Group. AAB Descriptions of Plant Viruses No. 339.

19. Woodford, J. A. T., Harrison, B. D., Aveyard, C. S., and Gordon, S. C. 1983. Insecticidal control of aphids and the spread of potato leafroll virus in potato crops in eastern Scotland Ann. Appl. Biol. 103:117-130. 